Fifth International Conference on Sustainable Construction Materials and

Technologies. http://www.claisse.info/Proceedings.htm

\title{
BIOGENIC TREATMENT IMPROVES THE DURABILITY OF STEEL SLAG AMENDED MORTAR STRUCTURES
}

\author{
M. Sudhakara Reddy ${ }^{1 *}$, Prabhdeep Kaur ${ }^{1}$, Sumit Joshi ${ }^{1}$, Omkar A Shinde ${ }^{2}$ \\ ${ }^{1}$ Department of Biotechnology, Thapar Institute of Engineering \& Technology, Patiala 147004, \\ Punjab, India; \\ ${ }^{2}$ Environment Research Group, Tata Steel Limited, R\&D and Scientific Services department, \\ Jamshedpur 831 007, India. .msreddy@ thapar.edu
}

\begin{abstract}
Steel slag is an industrial waste that is generated during the production of steel. Steel slag is a calcium-rich heterogenous solid consisting of several solid phases. Presence of high contents of free- $\mathrm{CaO}$ in steel slag endorses its cementitious property and makes it a potential candidate for alternate supplementary cementitious material. The usage of slag as a construction material is hindered by its volume instability due to its carbonation. In the present investigation, Staphylococcus pasteurii strain isolated from steel slag was tested for its ability to improve the durability properties of steel slag amended mortar specimens. In replacement of fine aggregate with steel slag (30\% and 50\%) along with microbial treatment, significant increase in compressive strength (28\%) and reduction in permeability ( 8 times) was observed in $30 \%$ slag amended mortar specimen as compare to control. Hence, microbial treatment along with steel slag usage in building materials provides an efficient way to enhance its properties as well as diminish environmental related concerns.
\end{abstract}

Key Words: Microbial concrete; Steel slag; Urease; Water absorption; Compressive strength; Calcium carbonate

\section{INTRODUCTION}

In the current scenario of urbanization and industrialization, infrastructure of a country plays an important role. In all the infrastructure categories, concrete is the most widely used construction material. With the continued demand, world without concrete is hard to imagine. In simplest form of definition concrete is a mixture of sand, aggregates, cement and water. Among these components of concrete, cement is the most important ingredient which acts as a binder material. Globally, production of cement has been escalated by cement companies to meet the requirement of construction projects. Emerging economies such as India and China are developing their infrastructure at a rapid pace. The cement production is a highly intensive energy consuming as well as a major $\mathrm{CO}_{2}$ emitting process (Worrell et al., 2001). It was reported that the total emissions in the industrial production of cement contributes $8 \%$ of global $\mathrm{CO}_{2}$ emissions (Andrew, 2018). The cement industry faces challenges to reduce global $\mathrm{CO}_{2}$ emissions and effectively contribute to sustainable development (Imbabi et al., 2012). In recent years, to address the environmental impact associated with cement production, researchers began to design new binders by partially replacing ordinary Portland cement (OPC) with supplementary cementitious materials (SCMs) 
(Juenger and Siddique, 2015; Aprianti, 2017). Developments in producing sustainable concrete by substituting cements or natural aggregates with waste by-products such as flyash, silica fumes, spent foundry sand, geopolymers and steel slag are reported (Chindaprasirt et al., 2007; Shi and Qian, 2003; Pedro et al ., 2017; Torres et al., 2017; Siddique et al., 2018; Singh et al., 2015; Tsakiridis et al., 2008; San-José et al., 2014). Large scale production of these by-products may lead to release of substantial amount of hazardous wastes due to improper disposal (Misra and Pandey, 2005). The use of such by-products in construction materials will not only be beneficial in minimizing the cost of construction but also helps in environment protection. Reusing the large volume of by-product in cement industry will contribute in sustainable development and reduce the problem of landfilling.

Among all the industrial waste products, steel slag is the fastest generated by-product produced from steel making industry. Global production of steel slag according to US Geological Survey was reported to be in order of 170 million to 250 million tons (Mo, 2018). Steel slag primarily consists of oxides of calcium, silicon, iron, magnesium, aluminum and small amounts of heavy metals. Presence of $\mathrm{C}_{3} \mathrm{~S}, \mathrm{C}_{2} \mathrm{~S}$, and $\mathrm{C}_{2} \mathrm{~F}$ in steel slag endorses its cementitious property (Shi, 2004). Effect of using steel slag in concrete research has been carried out by many researchers to improve the physical and chemical properties of concrete (Wang et al., 2013; Manso et al., 2006; Sorlini et al., 2012; Rosales et al., 2017; Maes et al., 2013). Various studies have reported that steel slag can act as a potential cement additive and concrete admixture with proper replacement (Yüksel, 2017). Instead of improved mechanical properties in steel slag amended concrete, volume expansion in structures also contributes disintegration as the time goes (Le et al., 2017). Due to the presence of excessive free (un-hydrated) lime ( $\mathrm{f}-\mathrm{CaO})$ and periclase (f-MgO) in slag, hydration causes volume instability. Hydration of free- $\mathrm{CaO}$ and $\mathrm{MgO}$ into hydroxide form increases the solid volume which further gives rise to microcracking (Brand and Roesler, 2015). To stabilize the effect of volume expansion, suitable methods must be adopted. Pretreatment of slag by leaving it in outdoor environment for months was reported to decrease free-CaO content from $1.20 \%$ to $0.61 \%$ (Le et al., 2017). To avoid open disposal in land and lengthy processing time, carbonation technique to stabilize slag is also reported (Mo, 2018).

In regard to sustainable developments in improving the durability properties of concrete, application of biomineralization in cement-based materials has become substantially popular. It is a microbial-based strategy in which concrete structures are treated with calcifying bacteria to induce calcium carbonate precipitation (Joshi et al., 2017). During the last decade, number of researchers had reported the potential of microbial induced calcium carbonate precipitation (MICP) in durability enhancement of concrete structures (Reddy and Joshi, 2018). MICP in a construction material can be made by supplementing ureolytic bacteria with calcium source along with urea (Joshi et al., 2018). The mechanism for MICP is described by the reactions:

$$
\begin{aligned}
& \mathrm{CO}\left(\mathrm{NH}_{2}\right)_{2}+2 \mathrm{H}_{2} \mathrm{O} \stackrel{\text { Bacteria }}{\longrightarrow} 2 \mathrm{NH}_{4}{ }^{+}+\mathrm{CO}_{3}{ }^{2-} \\
& \mathrm{Ca}^{2+}+\mathrm{CO}_{3}{ }^{2-} \longrightarrow \mathrm{CaCO}_{\downarrow} \longrightarrow
\end{aligned}
$$

In the context of steel slag amended mortar or concrete, previous studies mainly addresses the replacement of cement or aggregates with optimum levels of steel slag. In the present study, steel slag amended cement mortar will be treated with calcifying bacterial strain, isolated form steel slag. Current study also explores the feasibility of microbial stabilization of steel slag with the 
isolated bacterial strain. This research work evaluated the change in compressive strength, water absorption and microstructural analysis of microbial treated steel slag mortar.

\section{MATERIALS AND METHODS}

\section{Sample Site}

Steel slag samples were collected from Tata Steel Industries, Jamshedpur, India. Sample was sieved through predetermined sieve size of $4.75 \mathrm{~mm}$ and used for the isolation of calcifying bacteria.

\section{Isolation and Identification of Calcifying Bacteria}

For the isolation of bacteria involved in calcium carbonate $\left(\mathrm{CaCO}_{3}\right)$ precipitation, $2 \mathrm{~g}$ of steel slag sample was added in $100 \mathrm{~mL}$ nutrient broth (Hi-Media, Mumbai, India) (pH 8.0) containing 2\% urea and incubated at $37^{\circ} \mathrm{C}$ for $120 \mathrm{hrs}$ at $120 \mathrm{rpm}$. For isolation and enumeration of bacteria, the sample was serially diluted in saline $(0.85 \% \mathrm{NaCl})$ and plated on urea agar base medium and incubated at $37^{\circ} \mathrm{C}$ overnight. Intensity of pink colored halo zone around colonies indicated urease enzyme production. These colonies were selected for quantitative estimation of urease enzyme. For estimation of urease activity in urease positive isolates was determined according to phenolhypochlorite assay (Achal et al., 2010). Efficient bacteria capable of precipitating $\mathrm{CaCO}_{3}$ were identified based on 16S rRNA sequence analysis.

\section{Estimation of Soluble Calcium Content}

In order to stabilize the soluble calcium in slag by isolated bacterial strain, $1 \%$ inoculum of overnight grown bacterial culture in $100 \mathrm{ml}$ autoclaved nutrient broth (NB) medium (Peptone 10 $\mathrm{g} / \mathrm{L}$, Yeast extract $10 \mathrm{~g} / \mathrm{L}$, Sodium chloride $5 \mathrm{~g} / \mathrm{L}$ ) was inoculated. It was supplemented with filter sterilized $2 \%$ urea along with $5 \mathrm{gm}$ steel slag. Flask was incubated at $37^{\circ} \mathrm{C}$ in rotating shaker at $120 \mathrm{rpm}$ for 144 hours. The aliquots from flask was taken at regular time intervals of 24 hours and the broth was centrifuged to quantify soluble $\mathrm{Ca}^{2+}$ in the supernatant by EDTA titration method (Dhami et al., 2016).

\section{Biocementation in Slag Amended Cement Mortars}

Cement mortar mix was prepared by using cement: sand in the ratio of 1:3 (by weight) and water to cement ratio (w/c) of 0.5 . Cement and sand were thoroughly mixed for 2 min before adding water. To determine compressive strength and permeation properties, cube moulds of dimension $(50 \mathrm{~mm} \times 50 \mathrm{~mm} \times 50 \mathrm{~mm})$ were casted. For slag amended mortar, partial replacement of fine aggregate with slag (30\% and 50\%) was carried out. In bacterial treated slag mortars, partial replacement of fine aggregate was done along with grown bacterial culture. During casting, NB medium with bacterial culture $\left(\mathrm{OD}_{600}=0.5\right)$ supplemented with $2 \%$ urea $(\mathrm{w} / \mathrm{v})$ was used instead of water. After 24 hours of casting, specimens were demoulded and cured till the testing age. Mix proportions of different sets of cube samples with different curing regimes are specified in Table $1 \& 2$ respectively. 
Table 1. Mixture proportions of cement motar cubes (per $50 \mathrm{~mm}$ cube)

\begin{tabular}{|c|c|c|c|c|c|c|}
\hline \multirow{2}{*}{\multicolumn{2}{|c|}{ Composition }} & Control & \multicolumn{2}{|c|}{ Untreated } & \multicolumn{2}{|c|}{ Bacterial Treated } \\
\hline & & $\mathbf{C}$ & 30CS & $50 \mathrm{CS}$ & 30SBT & 50SBT \\
\hline \multicolumn{2}{|c|}{ Cement } & $76.2 \mathrm{~g}$ & $76.2 \mathrm{~g}$ & $76.2 \mathrm{~g}$ & $76.2 \mathrm{~g}$ & $76.2 \mathrm{~g}$ \\
\hline \multicolumn{2}{|c|}{ Fine Aggregate } & $228.6 \mathrm{~g}$ & $160.2 \mathrm{~g}$ & $114.3 \mathrm{~g}$ & $160.2 \mathrm{~g}$ & $114.3 \mathrm{~g}$ \\
\hline \multirow{2}{*}{ Slag } & 30\% Replacement & - & $68.58 \mathrm{~g}$ & - & $68.58 \mathrm{~g}$ & - \\
\hline & $50 \%$ Replacement & - & - & $114.3 \mathrm{~g}$ & - & $114.3 \mathrm{~g}$ \\
\hline \multicolumn{2}{|c|}{ Water } & $38.1 \mathrm{~g}$ & $38.1 \mathrm{~g}$ & $38.1 \mathrm{~g}$ & - & - \\
\hline \multicolumn{2}{|c|}{ Bacterial culture } & - & - & - & $38.1 \mathrm{~g}$ & $38.1 \mathrm{~g}$ \\
\hline
\end{tabular}

Table 2. Outline of different sets of mortar specimen and method of curing treatment

\begin{tabular}{|c|c|c|c|}
\hline \multicolumn{2}{|c|}{ Specimen } & Material & Method of curing \\
\hline \multicolumn{2}{|l|}{ Control } & $\begin{array}{l}\text { Cement:Sand } \\
\text { Water/Cement }=0.5\end{array}$ & $\begin{array}{l}\text { Water curing for } 7 \text { and } \\
28 \text { days }\end{array}$ \\
\hline \multicolumn{2}{|c|}{ Cement-Steel Slag } & $\begin{array}{l}\text { Cement:Sand:Slag } \\
\text { Water/Cement }=0.5\end{array}$ & $\begin{array}{l}\text { Water curing for } 7 \text { and } \\
28 \text { days }\end{array}$ \\
\hline \multirow{2}{*}{$\begin{array}{l}\text { Cement-Steel } \\
\text { slag \& } \\
\text { Bacterial } \\
\text { treated }\end{array}$} & 30\% Replacement & $\begin{array}{l}\text { Cement:Sand:Slag } \\
\text { Bacterial culture/Cement }=0.5\end{array}$ & $\begin{array}{l}\text { Submersion in NBU } \\
\text { medium and Bacterial } \\
\text { culture for } 7 \text { and } 28 \text { days }\end{array}$ \\
\hline & 50\% Replacement & $\begin{array}{l}\text { Cement:Sand:Slag } \\
\text { Bacterial culture/Cement }=0.5\end{array}$ & $\begin{array}{l}\text { Submersion in NBU } \\
\text { medium and Bacterial } \\
\text { culture for } 7 \text { and } 28 \text { days }\end{array}$ \\
\hline
\end{tabular}

NBU medium had the following concentration: Nutrient broth (Peptone $10 \mathrm{~g} / \mathrm{L}$, Yeast extract 10 $\mathrm{g} / \mathrm{L}$, Sodium chloride $5 \mathrm{~g} / \mathrm{L}$ ) and $2 \%$ Urea (w/v)

\section{Test Procedures}

To study the compressive strength, cement mortar cubes of $50 \mathrm{~mm}$ dimension was casted (BIS: 4031). Compressive strength of mortar cubes with/without steel slag and bacterial treatment were determined at the age of 7 and 28 days using an automatic compression testing machine, COMPTEST 3000.

Permeation properties of different mortar cubes as described in Table 1 were measured at 28 days of casting (Achal et al., 2011). For studying water absorption, all mortar samples were dried in oven at $60^{\circ} \mathrm{C}$ overnight and dry weight was measured $\left(\mathrm{W}_{\text {oven }}\right.$ dried). To calculate the rate of water absorption of specimens exposed to $10 \pm 1.0 \mathrm{~mm}$ of water were removed from the water and weighed at regular time intervals $(15 \mathrm{~min}, 30 \mathrm{~min}, 1 \mathrm{~h}, 1.5 \mathrm{~h}, 3 \mathrm{~h}, 5 \mathrm{~h}, 8 \mathrm{~h}, 24 \mathrm{~h}, 72 \mathrm{~h}, 96 \mathrm{~h}, 120 \mathrm{~h}$, $144 \mathrm{~h}$ and $168 \mathrm{~h}$ ). The sorptivity coefficient $\mathrm{k}\left[\mathrm{cm} \mathrm{s}^{-1 / 2}\right]$ was calculated from the following expression $\mathrm{Q} / \mathrm{A}=\mathrm{k}{ }_{\mathrm{t}}$. 
Here, $\mathrm{Q}$ is the amount of water absorbed $\left[\mathrm{cm}^{3}\right]$; $\mathrm{A}$ is the cross section of the cube which was in contact with water $\left[\mathrm{cm}^{2}\right] ; \mathrm{t}$ is the time [s]; Q/A is plotted against the square root of time, $\mathrm{k}$ is calculated from the slope of liner relation from these two.

To study the role of bacterial treatment in slag amended mortar, scanning electron microscopy (SEM) and Energy Dispersive X-ray spectroscopy (EDX) was performed in mortar specimens at the curing age of 28 days

\section{RESULTS AND DISCUSSION}

\section{Isolation and Identification of Calcifying Bacteria}

Primary screening for the selection of efficient bacterial strain from steel slag sample a qualitative test for urease production in urea agar media was done. Based on the pink color intensity out of twenty-four bacterial colonies, six were selected and designated as PP1, PP4, PP6, PP8, PP9, and PP11. The selected bacterial isolates were subjected to quantitative analysis of urease productivity. Among all the isolates, PP9 significantly produced higher urease activity and selected for further studies (Fig. 1).

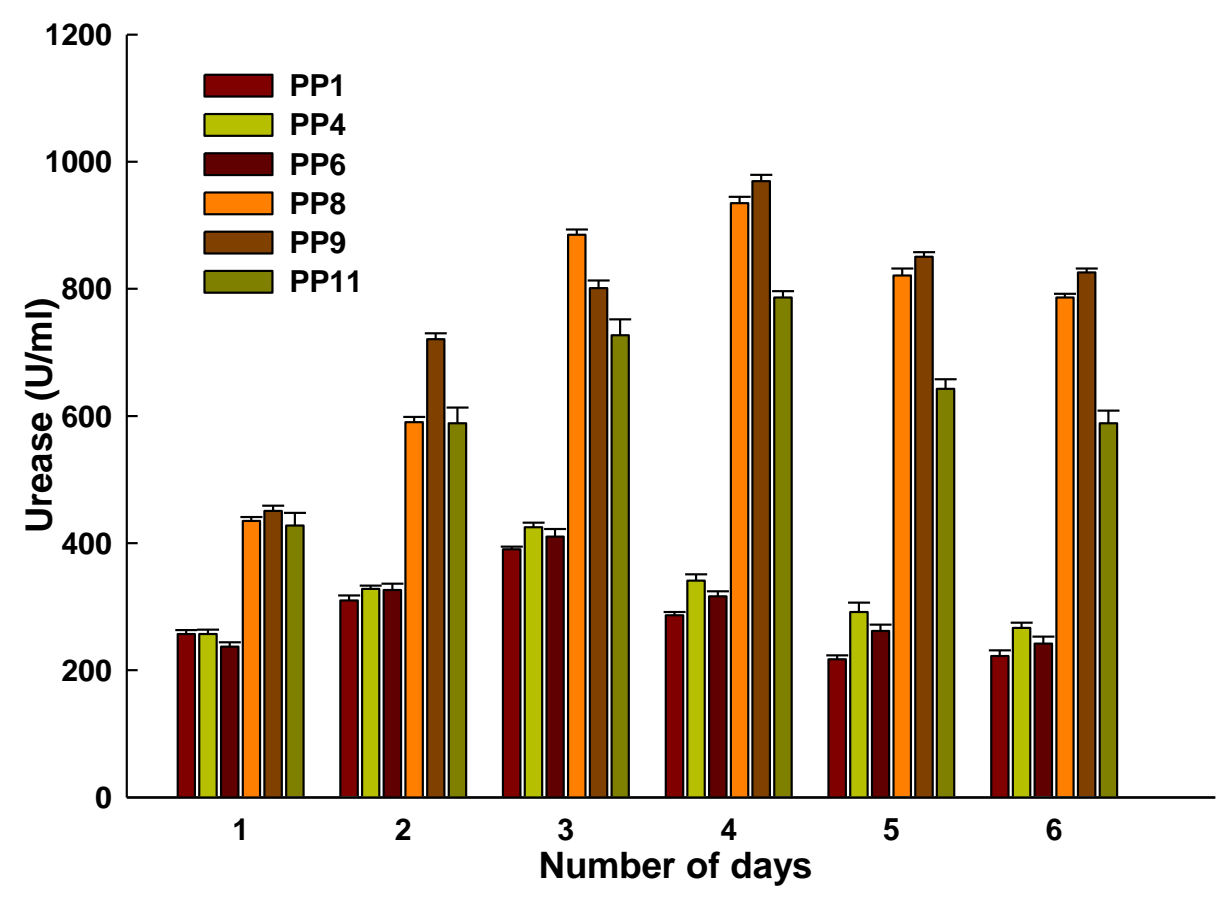

Fig. 1. Urease production (U/ml) by bacteria isolated from steel slag sample.

Since PP9 exhibited the maximum urease activity, it was considered for characterization subjected to 16S rRNA sequence analysis and was identified as Staphylococcus pasteurii. To study the pathogenicity of PP9, coagulase test and mannitol test were carried out and PP9 isolate was confirmed as nonpathogenic bacteria.

\section{Estimation of Soluble Calcium Content}

Soluble calcium content estimation by the bacterial isolate PP9 was evaluated at flask level by EDTA titration method. Initial readings of soluble calcium were noted to be the highest. The 
soluble calcium content was found to decrease with time due to its consumption by calcifying bacteria (Fig. 2). This indicates the conversion of available free-CaO content into $\mathrm{CaCO}_{3}$ precipitation as soluble calcium content is converted to $\mathrm{CaCO}_{3}$ crystals by PP9.

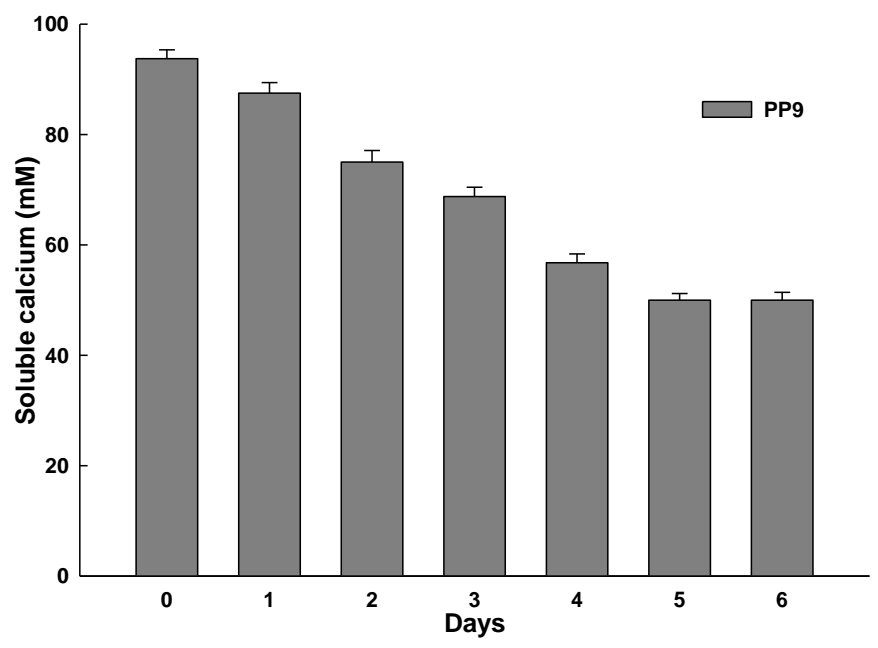

Fig. 2. Variation in soluble calcium content of medium inoculated with PP9

\section{Mechanical and Permeation Analysis}

\section{Compressive Strength}

Effect of bacterial treatment and slag replacement on compressive strength of mortar samples was monitored after 7 and 28 days curing (Fig. 3). Control specimen showed compressive strength value of $20.6 \mathrm{MPa}$ and $24 \mathrm{MPa}$ at the age of 7 and 28 days respectively. When compared to control, no significant change in strength was observed in 30CS and 50CS specimens after 7 days curing. However, after 28 days of curing 30CS and 50CS specimens showed an increase of $13.75 \%$ and 9.5\% in compressive strength as compare to control. The bacterial treated specimens along with slag replacement showed notable change in strength. At the age of 28 days, it was observed that $28 \%$ increase in compressive strength of 30SBT specimen as compared to control.

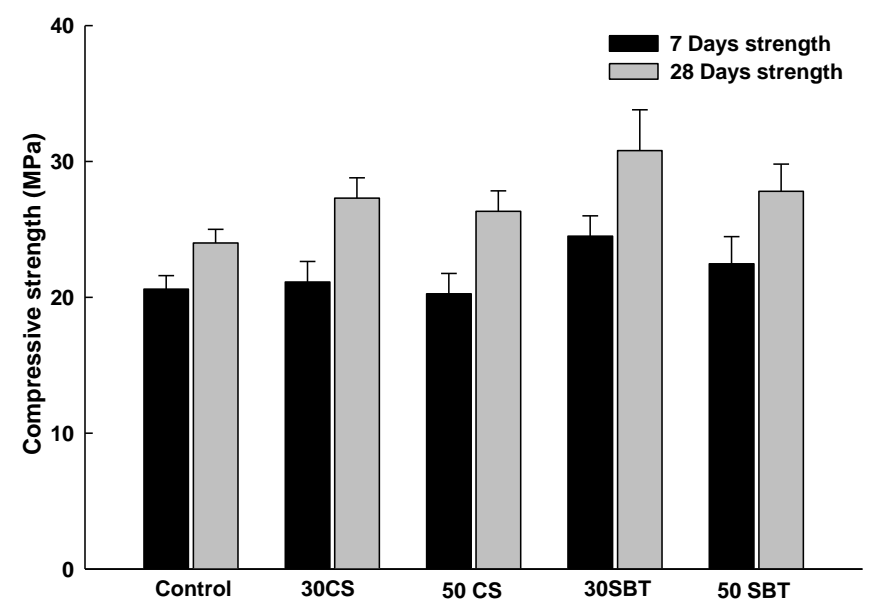


Fig. 3 Influence of steel slag and bacterial treatment on compressive strength (MPa) of mortar specimen

However, 50SBT specimen showed only $15 \%$ increase in strength when compared to control. It was observed that as the amount of steel slag replacement was increased from $30 \%$ to $50 \%$, overall strength decreased. It was observed that the application of MICP technology along with 30\% replacement of fine aggregates with steel slag improved the mechanical strength of 30SBT specimen. Due to dense biodeposition of calcium carbonate precipitation helped in densifying the mortar matrix. Similar observation of increased strength in microbial mineralized steel slag bricks due to deposition of $\mathrm{CaCO}_{3}$ crystals was reported (Wang et al., 2016).

\section{Water Absorption Test}

Among all the specimens, control mortar has highest water absorption followed by 30CS and 50 CS specimens (Fig. 4). The specimens treated with bacteria either 30SBT or 50SBT registered significantly lowest water absorption as compared to control. It was concluded that the bacterially treated specimen 30SBT absorbed nearly eight times less water as compared to the control specimen. Almost similar trend of water absorption was observed in 50SBT specimen.



Fig. 4 Capillary water absorption of mortar specimen amended with steel slag and treated with bacteria

The reduction in the extent of water absorption may be attributed to the fact that due to bacterial calcification, $\mathrm{CACO}_{3}$ crystals were deposited. This reduced the pores on the surface of the cement mortar cubes leading to protective film coating, which prevented ingress of water. The results obtained in water absorption test indicated that in 30SBT and 50 SBT specimens, the transport mechanism of water through capillary rise was altered effectively. Bacterial treatment significantly restricts the ingress of water and aggressive agents and blocks the pore with $\mathrm{CaCO}_{3}$ precipitation. Similar trend of reduced water absorption in fly ash amended mortar specimen due to bio deposition was also reported (Achal et al., 2011). 


\section{Microstructural Analysis}

Scanning electron micrograph and Energy dispersive $\mathrm{X}$ ray spectrum of 50SBT (Fig. 5A and 5B) and 30SBT (Fig. 5C and 5D) cement mortar was studied.

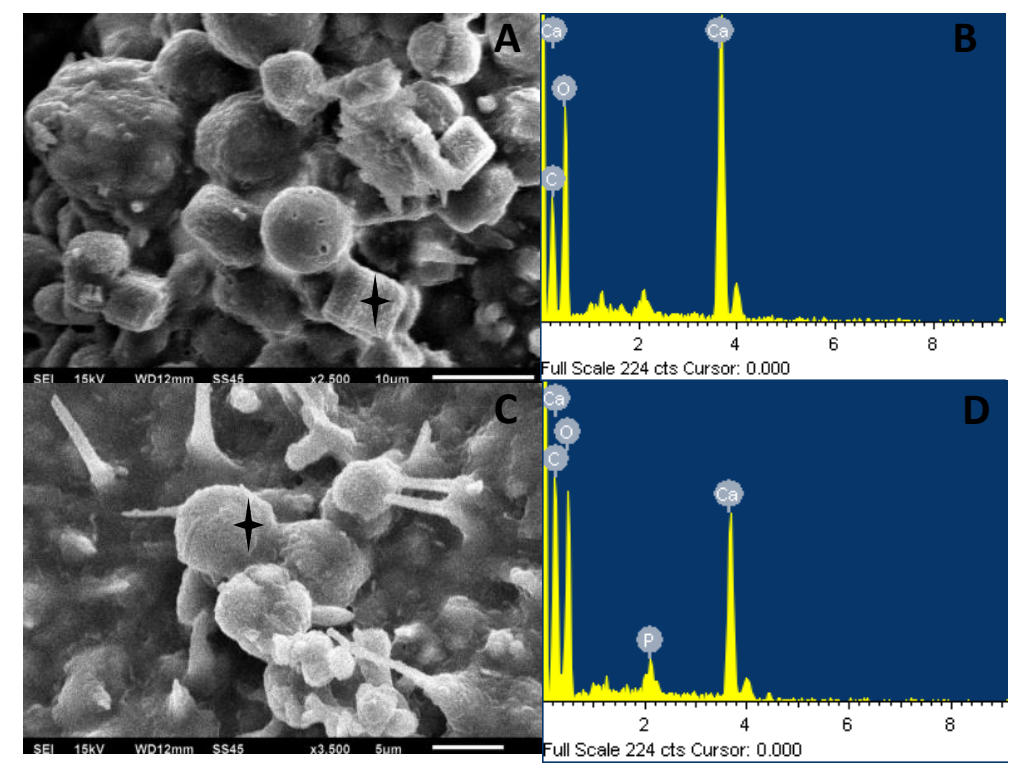

Fig. 5. Scanning electron micrograph and Energy dispersive $X$ ray spectrum of $\operatorname{50SBT}(\mathrm{A}, \mathrm{B})$ and $30 \mathrm{SBT}(\mathrm{C}, \mathrm{D})$

Distinct rhombohedral calcite and spheroid vaterite crystals were observed in close proximity of the bacterial cells. EDX analysis confirmed the elemental composition of crystals showing high peaks of calcium and carbon in 30SBT and 50SBT (Fig. 5B and 5D).

\section{CONCLUSIONS}

A calcifying bacterial strain with high urease activity was isolated from steel slag. Which was identified as Staphylococcus pasteruii based on its $16 \mathrm{~S}$ rRNA sequence analysis. In replacement of fine aggregate with steel slag (30\% and 50\%) along with microbial treatment, 30SBT specimen exhibited the highest strength gain of $28 \%$ and the water ingress was reduced by eight times as compared to the control specimen. SEM analysis endorsed the involvement of bacterial cells in $\mathrm{CaCO}_{3}$ precipitation. Polymorphs of calcium carbonate crystals were identified as calcite and vaterite. In conclusion, this study paved the way for sustainable production of eco-friendly building material using MICP technology and use of steel slag as an aggregate in concrete structures. 


\section{REFERENCES}

Achal, V., Mukherjee, A. and Reddy, M.S. (2010) "Microbial concrete: way to enhance the durability of building structures" J. Mater. Civil. Eng., 23, 730-734.

Achal, V., Pan, X. and Özyurt, N. (2011) "Improved strength and durability of fly ash-amended concrete by microbial calcite precipitation" Ecol. Eng., 37, 554-559.

Andrew, R.M. (2018) "Global CO 2 emissions from cement production" Earth Syst. Sci. Data, 10(1), 195.

Aprianti, E. (2017) "A huge number of artificial waste material can be supplementary cementitious material (SCM) for concrete production-a review part II" J. Clean. Prod., 142, 4178-4194.

BIS: 4031 (2000) Methods of physical tests for hydraulic cements. Part 6. Determination of compressive strength of hydraulic cement other than masonry cement. Bureau of Indian Standards, New Delhi, India.

Brand, A.S. and Roesler, J.R. (2015) "Steel furnace slag aggregate expansion and hardened concrete properties" Cement. Concrete. Comp., 60, 1-9.

Chindaprasirt, P., Jaturapitakkul, C. and Sinsiri, T. (2007) "Effect of fly ash fineness on microstructure of blended cement paste" Constr. Build. Mater., 21(7), 1534-1541.

Dhami, N.K., Reddy, M.S. and Mukherjee, A. (2016) "Significant indicators for biomineralisation in sand of varying grain sizes" Constr. Build. Mater., 104, 198-207.

Imbabi, M.S., Carrigan, C. and McKenna, S. (2012) "Trends and developments in green cement and concrete technology" International Journal of Sustainable Built Environment, 1(2), 194216.

Joshi, S., Goyal, S. and Reddy, M.S. (2018) "Influence of nutrient components of media on structural properties of concrete during biocementation" Constr. Build. Mater., 158, 601-613.

Joshi, S., Goyal, S., Mukherjee, A. and Reddy, M.S. (2017) "Microbial healing of cracks in concrete: a review" J. Ind. Microbiol. Biot., 44, 1511-1525.

Juenger, M.C. and Siddique, R. (2015) "Recent advances in understanding the role of supplementary cementitious materials in concrete" Cement. Concrete. Res., 78, 71-80.

Le, D.H., Sheen, Y.N. and Bui, Q.B. (2017) "An assessment on volume stabilization of mortar with stainless steel slag sand" Constr. Build. Mater., 155, 200-208.

Maes, M., Gruyaert, E. and De Belie, N. (2013) "Resistance of concrete with blast-furnace slag against chlorides, investigated by comparing chloride profiles after migration and diffusion" Mater. Struct., 46, 89-103.

Manso, J.M., Polanco, J.A., Losanez, M. and Gonzalez, J.J. (2006) "Durability of concrete made with EAF slag as aggregate" Cement. Concrete. Comp., 28, 528-534. 
Misra, V. and Pandey, S.D. (2005) "Hazardous waste, impact on health and environment for development of better waste management strategies in future in India" Environ. Int., 31, 417431.

Mo, L. (2018) "Carbon dioxide sequestration on steel slag" In Carbon Dioxide Sequestration in Cementitious Construction Materials, 175-197.

Pedro, D., De Brito, J. and Evangelista, L. (2017) "Evaluation of high-performance concrete with recycled aggregates: Use of densified silica fume as cement replacement" Constr. Build. Mater., 147, 803-814.

Reddy, M.S. and Joshi, S. (2018) "Carbon dioxide sequestration on biocement-based composites" In Carbon Dioxide Sequestration in Cementitious Construction Materials, 225-243.

Rosales, J., Cabrera, M. and Agrela, F. (2017) "Effect of stainless steel slag waste as a replacement for cement in mortars" Mechanical and statistical study. Constr. Build. Mater., $142,444-458$.

San-José, J.T., Vegas, I., Arribas, I. and Marcos, I. (2014) “The performance of steel-making slag concretes in the hardened state" Mater. Design., 60, 612-619.

Shi, C. (2004) "Steel slag-its production, processing, characteristics, and cementitious properties" J Mater Civil Eng, 16, 230-236.

Shi, C. and Qian, J. (2003) "Increasing coal fly ash use in cement and concrete through chemical activation of reactivity of fly ash" Energ. Source., 25(6),617-628.

Siddique, R., Singh, G. and Singh, M. (2018) "Recycle option for metallurgical by-product (Spent Foundry Sand) in green concrete for sustainable construction" J. Clean. Prod., 172, 11111120.

Singh, B., Ishwarya, G., Gupta, M. and Bhattacharyya, S.K. (2015) "Geopolymer concrete: A review of some recent developments" Constr. Build. Mater., 85, 78-90.

Sorlini, S., Sanzeni, A. and Rondi, L. (2012) "Reuse of steel slag in bituminous paving mixtures" J. Hazard. Mater., 209, 84-91.

Torres, A., Bartlett, L. and Pilgrim, C. (2017) "Effect of foundry waste on the mechanical properties of Portland Cement Concrete" Constr. Build. Mater., 135, 674-681.

Tsakiridis, P.E., Papadimitriou, G.D., Tsivilis, S. and Koroneos, C. (2008) "Utilization of steel slag for Portland cement clinker production” J. Hazard. Mater., 152, 805-811.

Wang, K., Qian, C. and Wang, R. (2016) “The properties and mechanism of microbial mineralized steel slag bricks" Constr. Build. Mater., 113, 815-823.

Wang, Q., Yan, P., Yang, J. and Zhang, B. (2013) "Influence of steel slag on mechanical properties and durability of concrete" Constr. Build. Mater., 47, 1414-1420. 
Worrell, E., Price, L., Martin, N., Hendriks, C., and Meida, L.O. (2001) "Carbon dioxide emissions from the global cement industry" Annual review of energy and the environment, 26(1), 303-329.

Yüksel, İ. (2017) "A review of steel slag usage in construction industry for sustainable development” Environ. Dev. Sustain., 19, 369-384. 